\title{
MORPHOLOGY OF SUBSTANCE P IMMUNOREACTIVE NEURONS IN HUMAN CORTEX OF THE INFERIOR PARIETAL LOBULE
}

\author{
Christos G. Alexopoulos, ${ }^{1}$ Laslo Puskas, ${ }^{2}$ Biljana Ilic, ${ }^{3}$ Maja Jevcevic, ${ }^{1}$ Slobodanka Mitrovic, ${ }^{4}$ Maja Sazdanovic, ${ }^{5}$ \\ Neda Ognjanovic, ${ }^{6}$ Predrag Sazdanovic ${ }^{6}$ \\ ${ }^{1}$ Department of Anatomy, College of Health Studies, Cuprija, Serbia \\ 2 Department of Anatomy, Medical Faculty, University of Belgrade, Belgrade, Serbia \\ ${ }^{3}$ College of Health Studies, Cuprija, Serbia \\ ${ }^{4}$ Department of Pathology, Faculty of Medical Sciences, University of Kragujevac, Kragujevac, Serbia \\ ${ }^{5}$ Department of Histology and Embryology, Faculty of Medical Sciences, University of Kragujevac, Kragujevac, Serbia \\ ${ }^{6}$ Department of Anatomy, Faculty of Medical Sciences, University of Kragujevac, Kragujevac, Serbia

\section{MORFOLOGIJA NEURONA IMUNOREAKTIVNIH NA SUPSTANCU P U HUMANOM KORTEKSU DONJEG PARIJETALNOG REŽNJA}

\author{
Hristos G. Aleksopulos, ${ }^{1}$ Laslo Puškaš, ${ }^{2}$ Biljana Ilić, ${ }^{3}$ Maja Jevčević, ${ }^{1}$ Slobodanka Mitrović, 4 Maja Sazdanović, 5 \\ Neda Ognjanović, 6 Predrag Sazdanović 6 \\ ${ }^{1}$ Katedra za anatomiju, Visoka medicinska škola stukovnih studija, Ćuprija \\ ${ }^{2}$ Katedra za anatomiju, Medicinski fakultet, Univerzitet u Beogradu, Beograd \\ 3 Visoka medicinska škola stukovnih studija, Ćuprija \\ ${ }^{4}$ Katedra za patologiju, Fakultet medicinskih nauka, Univerzitet u Kragujevcu, Kragujevac \\ ${ }_{5}^{5}$ Katedra za histologiju i embriologiju, Fakultet medicinskih nauka, Univerzitet u Kragujevcu, Kragujevac \\ ${ }^{6}$ Katedra za anatomiju, Fakultet medicinskih nauka, Univerzitet u Kragujevcu, Kragujevac
}

\section{ABSTRACT}

Objective. This study was conducted in order to find out whether there was any particular association between the neuronal body shapes and their immunoreactivity on substance $P$ neurons in the supramarginal and angular gyri of inferior parietal lobule (IPL).

Methods. Substance P (SP) neuropeptide was examined in the human brain (3 male and 4 female) without any neurological and psychiatric diseases, by using the method of immunohistochemistry. Immunoreactive neurons and fibers were visualized by using Olympus BT2 Camera Lucida. The collected data were statistically analyzed by using one-way analysis of variance, with the probability level $p=<0.05$.

Results. The largest somas were obtained among SP positive neurons. Average diameters ( $\pm S D$ ) were: longer diameter $44.93 \pm 15.69 \mu \mathrm{m}$, shorter diameter $18.16 \pm 3.77$ $\mu m$. One-way analysis of variance revealed the highly significant difference among the longer axis of immunopositive neurons ( $p=0.002$ ).

Conclusion. A quarter of detected SP neurons were localized in lamina II of the IPL cortex. The least populated layer was lamina I (less than a tenth of all immunoreactive neurons).

Key words: parietal lobe; cerebral cortex; neuropeptides; substance P; immunohistochemistry.

\section{INTRODUCTION}

Supramarginal (SG) and angular (AG) are the principal gyri of the inferior parietal lobule (IPL). Its cortex belongs to two Brodmann's divisions: areas 39 (AG) and 40 (SG). According to Eidelberg and Galaburda parcellation cortex of IPL could be distinguished into further areas, three of

\section{SAŽETAK}

Cilj. Studija je sprovedena da bi se saznalo postoji li određena povezanost između oblika tela neurona i njihove imunoreaktivnosti na supstancu $P u$ supramarginalnom $i$ angularnoj vijuzi donjeg parijetalnog moždanog režnja.

Metode. Supstanca $P(S P)$ neuropeptid ispitivan je $u$ ljudskom mozgu (3 muška i 4 ženska), bez ikakvih neuroloških $i$ psihijatrijskih oboljenja, metodom immunohistohemije. Koristeći „Olympus BT2 Camera Lucida“ opremu, imunoreaktivni neuroni $i$ vlakna su vizualizovani. Prikupljeni podaci su statistički analizirani upotrebom jednofaktorske analize varijanse sa nivoom verovatnoće $p \leq$ 0,05 .

Rezultati. Najveća tela neurona su otkrivena kod SP pozitivnih neurona: prosečni prečnici ( $\pm S D$ ) bili su: duži prečnik 44,93 $\pm 15,69 \mu \mathrm{m}$, kraći prečnik 18,16 \pm 3,77 $\mu \mathrm{m}$. Jednofaktorska analiza varijanse pokazala je visoko značajne razlike između dužih osa immunopositivnih neurona $(p=0,002)$.

Zaključak. Četvrtina otkrivenih SP neurona su lokalizovani u lamini II korteksa donjeg parijetalnog moždanog režnja. Sloj sa najmanjom gustinom lamina I (manje od jedne desetine svih imunoreaktivnih neurona).

Ključne reči: parijetalni režanj; moždani korteks; neuropeptidi, supstanca P; imunohistohemija.

which belong to $A G$ and remaining belong to $S G$ (1). One of the prominent characteristics of parietal cortex is layer IV. These densely granulated regions are organized in a few islands and surrounded by thinner, granular cortex layer IV (2). This typical island pattern of parietal cortex is found in humans and primates (3). 
Development of parietal lobule strongly depends on external stimuli (4). According to its heteromodel association role, human IPL was reported to display sexual differences in cortex volumes (5-7). According to Blaxton and associates lateral aspects of bilateral parietal lobule are under the influence of conceptual tasks as well as medial and lateral left hemisphere in frontal and temporal regions (8).

Due to the rapid development in technologies indispensable for the investigation of neurotransmitters in neuroscience, the last few decades have been named "transmitter's decades" (9-14). Substance P (SP) is a peptide consisting of 11 aminoacids that was discovered in 1931 (15). It represents the primary sensory afferent transmitter in the spinal cord. In Alzheimer's disease drastic decrease of number of neurons was found, especially in parietal cortex (16). The SP transmitters of primary gastrointestinal origin were reported to be significantly reduced in schizophrenia. Neuropeptide deficit was more pronounced in temporal and frontal lobe of schizophrenics (17).

The goal of this study was to find out SP neurons in IPL and its morphological determinations such as neuronal distribution, soma measurements, and dendrite branches.

\section{MATERIAL AND METHODS}

We examined seven human brains of both sexes ( 3 male and 4 female) without any neurological and psychiatric diseases. The method had previously been described in details (18). After Zamboni fixative perfusion, 3-6 hours after death, we left brains in the same solution for 7 days. After the identification of AG and SG from IPL, we postfixated 3 days and then immersed into sucrose solution for 48 hours. They were cut serially into frozen sections of 40 um thickness. The slices were completely washed from fixative with $0.1 \mathrm{M}$ phosphate buffer 5 times during 2 hours. Free-floating sections were permeabilized with $0.5 \%$ Tritron X-100 solution overnight and we made block from endogenous peroxidase using 3\% $\mathrm{H}_{2} \mathrm{O}_{2}$ for 10 minutes.

The slices were incubated in $10 \%$ normal goat serum (Miles Lab., Napperville) for 1 hour at room temperature and after that the slices were incubated for 48 hours at $4{ }^{\circ} \mathrm{C}$ in primary antibodies of various dilutions: SP-1 (1:20000) (R.L. Eskay, Bethesda, USA) (15). The sections were incubated in 1:500 biotinylated anti-rabbit $\mathrm{IgG}$ solution after rinsing in phosphate buffer and then in biotinylated avidin-peroxidase complex (1:250) (Vector Labs, Burlingame, USA). Between incubation steps, the sections were washed in three changes of $0.1 \mathrm{M}$ PB. After the last wash in $\mathrm{PB}$, sections were further rinsed in $50 \mathrm{mM}$ Tris$\mathrm{HCl}$ buffer ( $\mathrm{pH}$ 7.6). Sections were developed in Tris- $\mathrm{HCl}$ buffer containing $0.02 \% 3.3$ diaminobenzidine (DAB),
$0.6 \%$ nickel-ammonium-sulfate and $0.02 \% \mathrm{H}_{2} \mathrm{O}_{2}$ for 10 minutes, mounted and coverslipped. Using Olympus BT2 Camera Lucida, immunoreactive neurons and fibers were traced.

The study was conducted according to the institutional ethical requirements, complying with contemporary, widely accepted, ethical standards. The collected data were statistically analyzed using one-way analysis of variance (ANOVA), with the probability level $=<0.05$.

\section{RESULTS}

The lowest appearance was detected in SP immunopositive neurons: only $13.5 \%$ of the observed neurons. No presence of SP was detected in the layers $\mathrm{V}$ and VI. The largest somata were obtained among SP positive neurons: the mean diameters ( \pm standard deviation, SD) were: longer diameter $44.93 \pm 15.69 \mu \mathrm{m}$, shorter diameter $18.16 \pm 3.77 \mu \mathrm{m}$. One-way analysis of variance (ANOVA) revealed the highly significant difference among longer axis of immunopositive neurons $(p=0.002)$. Most of the detected neurons $(25 \%)$ were localized in lamina II of the LPI cortex. The least populated layer was lamina I (less than $10 \%$ of all immunoreactive neurons).

SP-1 immunoreactive neurons were rare, scattered and mostly present from layer I to layer IV. Generally, this was the smallest population of the sample and no statistical processing could be applied. The layers I and IV were poorly populated with this type of neurons (only one soma in each lamina).

The following occurred in IPL cortex. In layer I small Cajal-Retzius neuron with simple, short two dendrites (dendritic radius $85 \mu \mathrm{m}$ ) arising from the opposite pole of the cell body. Dendrites of these cells are smooth and without processes (figure 1). Bipolar SP IR is middle so small soma (major cell body axis $12 \mu \mathrm{m}$ and minor cell body axis $10 \mu \mathrm{m}$ ) and located in layer III. Bitufted type SP IR cells from the layer II were oval in shape, with narrow dendritic trees (2-4 dendrites) and axon emerging from the lower dendritic tuft (figure 2). Multipolar SP IR neurons had ovoid perikarya (major cell body diameter 22-34 $\mu \mathrm{m}$ and minor cell body diameter 13 to $16 \mu \mathrm{m}), 3-4$ smooth dendrites spread in the radiuses between $97-140 \mu \mathrm{m}$ from the perikaryon. This type was representative for the layer III of the IPL cortex (figure 1). Layer IV of the IPL cortex contained one small pyramidal SP IR neuron.

\section{DISCUSSION}

We did not find any differences between the bipolar Golgi neuron classifications and SP immunoreactive neurons. We found the same perikaryon asymmetry, in the middle of the IPL cortex, had symmetrical dendritic 
I

II

III

IV

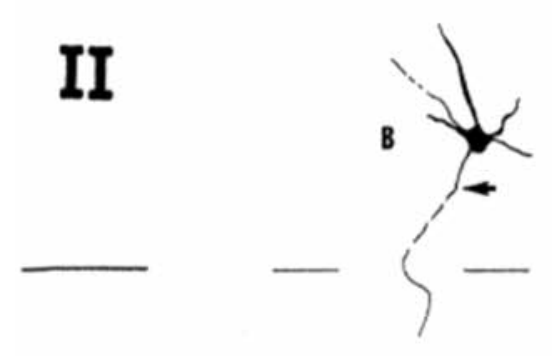

$A \sim$
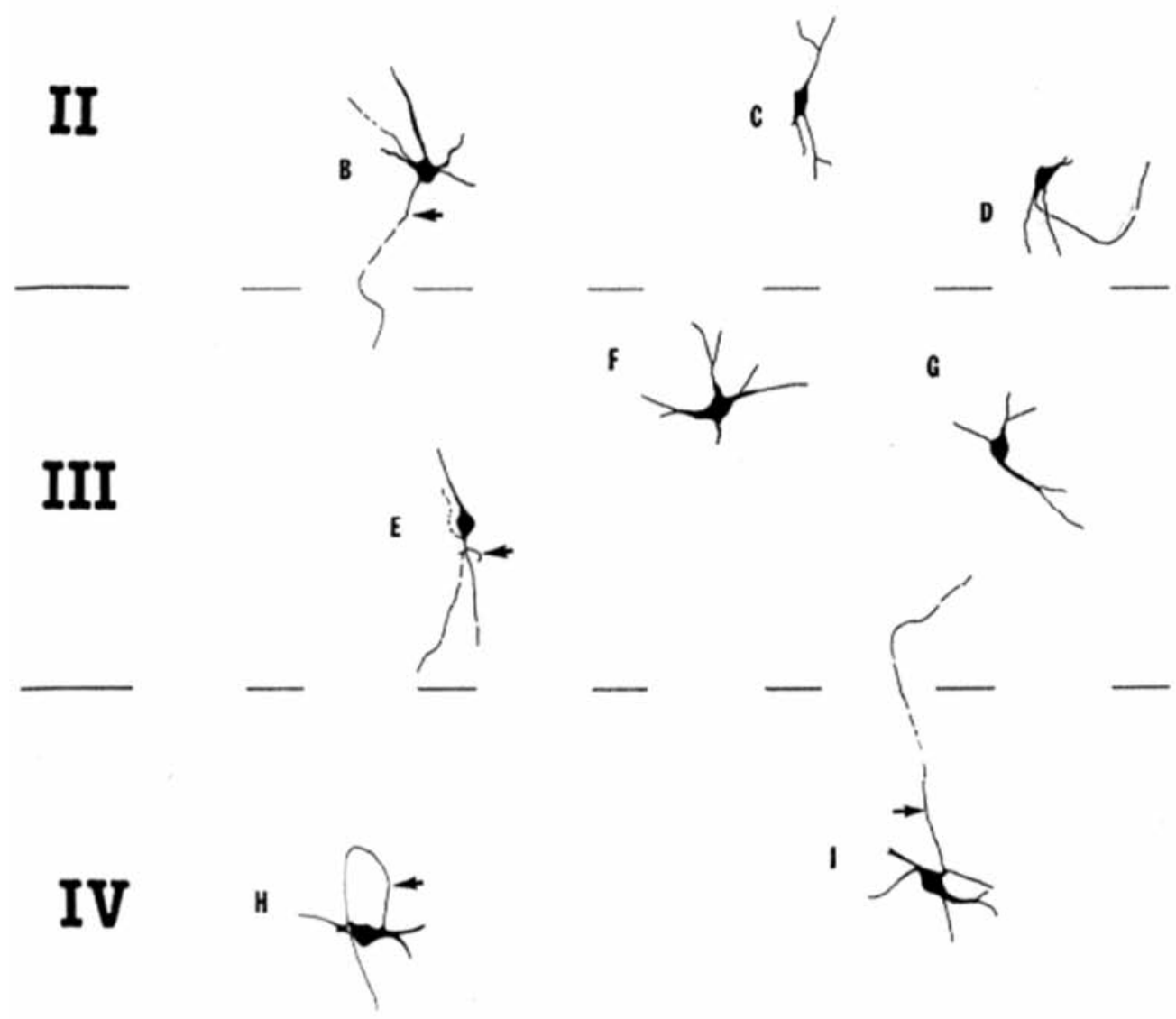

V

VI
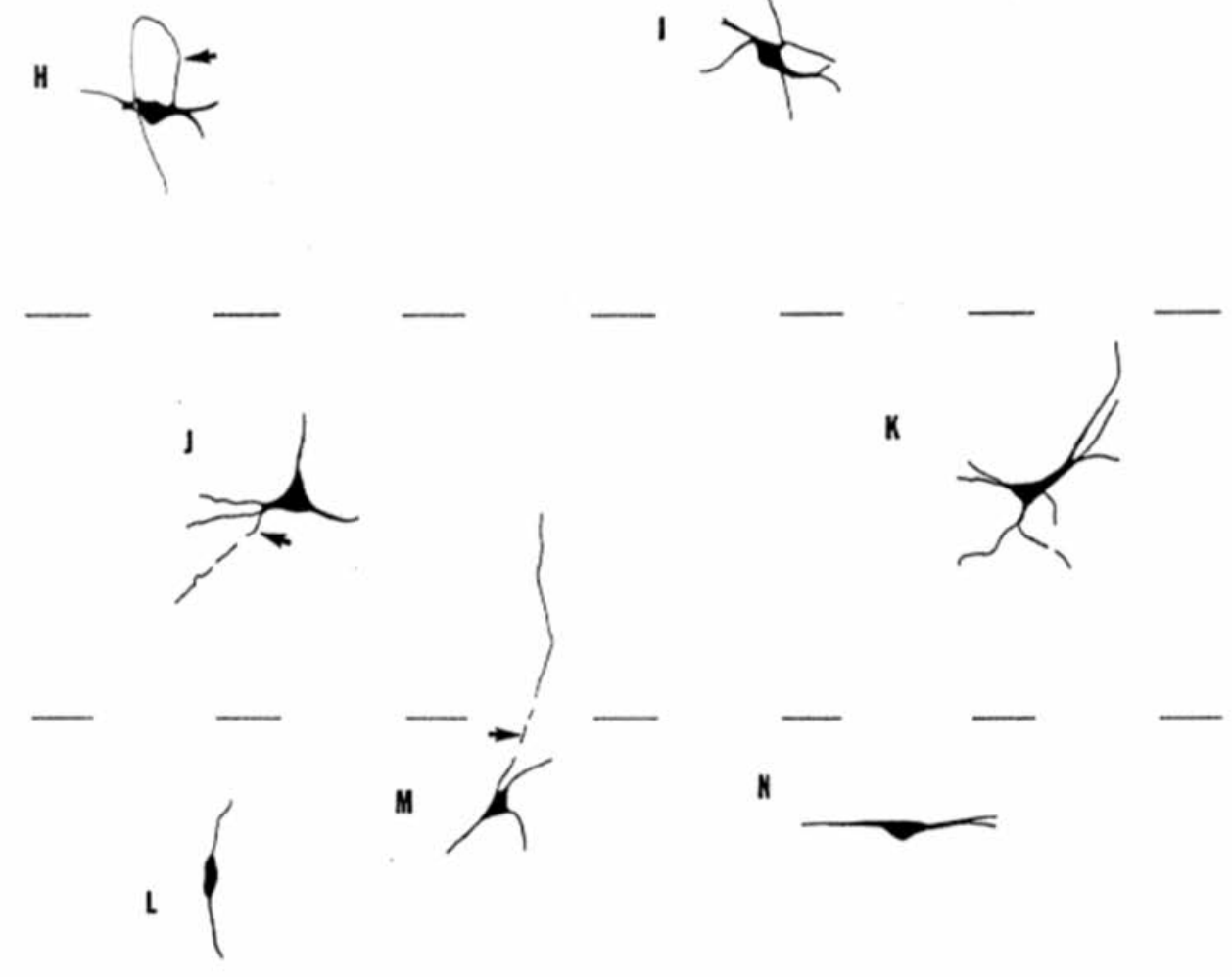

$0.1 \mathrm{~mm}$

Figure 1. Dendrites of neurons in the IPL cortex layers. 


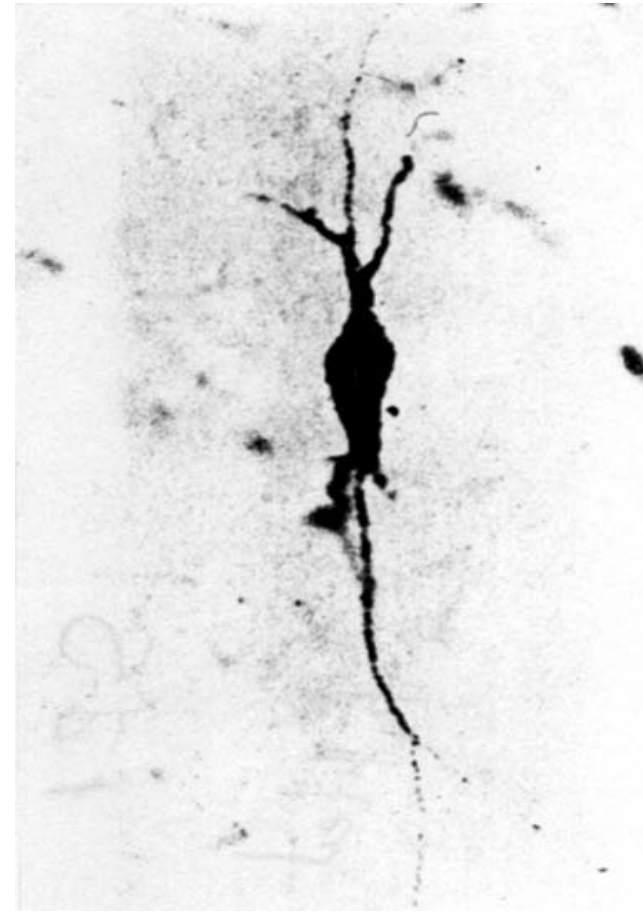

Figure 2. Bitufted type SP IR cells from the layer II.

arborisation (19-21). Parietal cortex has a very important role in brain function, particularly for somatosensory systems like pain pathways (22).

Substance P, leucine-enkephalin (L-ENK) system stands quite opposite to the excitatory transmitters. It has been stated that its concentrations in many structures of the brain raises after induced, epileptic-like, convulsions on the experimental animals (23-26), but, in general, its concentration in brain is low (27). Distribution of L-ENK neurons, obtained in this investigation, might indicate its role in general regulation of neuronal transmission, probably with inhibiting influence. Our opinion is reinforced by the fact that L-ENK concentration rose in patients with hypersomnia and that it plays an inhibiting role to the cortical and reticular formation activities (28, 29).

According to SP neuropeptide enrollment, we noticed morphological variations in the shape of the neuronal soma. These complexities of morphological presents are expected according to huge variations of cortical functions. Findings in this paper are invitation for further investigations of neuron morphology from different neurotransmitters.

\section{ABBREVIATIONS}

SG - Supramarginal gyrus

AG - Angular gyrus

SP - Substance P

IPL - inferior parietal lobule

\section{REFERENCES}

1. Eidelberg, D. Galaburda. A. Inferior parietal lobule. Divergent architectonic asymmetries in the human brain. Arch Neurol 1984; 41: 843-52.

2. Jones EG, Peters A. Cerebral cortex. Volume 1. New York-London: Plenum Press, 1984.

3. Haug H. Brain sizes, surfaces and neuronal sizes of the cortex cerebri: A stereological investigation of man and his variability and a comparison with some mammals (primates, whales, marsupials, insectivores and one elephant). Am J Anat 1987; 180: 126-42.

4. Kappers A, Huber C, Crosby E. The comparative anatomy of the nervous system of vertebrates including man. New York: Hafner Publishing Company, 1960.

5. Fredrikse ME, Lu A, Ayward E, Barta P, Pearlson G. Sex differences in the inferior parietal lobule. Cereb Cortex 1999; 9: 896-901.

6. Okada T, Tanaka S, Nakai T, et al. Naming of animals and tools: a functional magnetic resonance imaging study of categorical differences in the human brain areas commonly used for naming visually presented objects. Neurosci Lett 2000; 296: 33-6.

7. Svensson P, Minoshima S, Beydoun A, Morrow TJ, Casey KL. Cerebral processing of acute skin and muscle pain in humans. J Neuropsychol 1997; 78: 450-60.

8. Blaxton TA, Bookheimer SY, Zeffiro TA, Figolzzi CM, Gaillard WD, Theodore WH. Functional mapping of human memory using PET: comparisons of conceptual and perceptual tasks. Can J Exp Psychol 1996; 50: 42-56.

9. Heimer L. Human brain and spinal cord, functional neuroanatomy and dissection guide. New York Springer-Verlag, 1995.

10. Peters A, Miler M, Kimerer L. Cholecystokinin-like immunoreactive neurons in rat cerebral cortex. Neuroscience 1983; 8: 431-48.

11. Beinfeld MC, Meyer DK, Eskay RL, Jensen RT, Browstein MJ. The distribution of cholecystokinin immuno-reactivity in the central nervous system of the rat as determined by radioimmunoassay. Brain Res 1981: 212: 51-7.

12. Taquet HF, Javoy-Agid A, Maugborne J, et al. Biochemical mapping of cholecystokinin, substance P, methionine (Met) enkephalin, leucine (Leu) enkephalin and dynorphin A (1-8) - like immunoreactivities in the human cerebral cortex. Neuroscience 1988; 27: 871-83.

13. Tachikawa H, Harada S, Kawanishi Y, Okubo T, Shiraishi H. Novel polymorphisms of the human cholecystokinin A receptor gene as an association analysis with schizophrenia. Am J Genet 2000; 96: 141-5. 
14. Kryzhanovskii GN, Lutsenko VK, Khlebnikova NN. The effects of the leucine enkephalin on the development of a convulsive after discharge in the sensomotor cortex in rats. Bull Exp Biol Med 1992; 114: 343-5.

15. Von Euler US, Gaddum JH. An unidentified depressor substance in certain tissue extracts. J Physiol 1931; 72: 74-87.

16. Quigley BJ, Kowall NW. Substance P-like immunoreactive neurons are depleted in Alzheimer's disease cerebral cortex. Neuroscience 1991; 41: 41-60.

17. Gabriel SM, Davidson M, Haroutunian V, et al. Neuropeptide deficit in schizophrenia vs. Alzheimer's disease cerebral cortex. Biol Psychiatry 1996; 15: 82-91.

18. Aleksopoulos HG, Puskas L, Ilic MB, Jovic ZC, Milenkovic MM, Stojanović ZV. Histochemical study on cholecystokinin and morphology of immunopositive neurons in the cortex of human inferior parietal lobule. PONS Med J 2009; 6(20): 1-5.

19. Baffi J, Görcs T, Slowik F, et al. Neuropeptides in the human superior cervical ganglion. Brain Res 1992; 570: 272-8.

20. Peters A, Miler M, Kimerer L. Cholecystokinin-like immunoreactive neurons in rat cerebral cortex. Neuroscience 1983; 8: 431-48.

21. Serogy B, Fallon H, Loughlin E, Leslie M. Few cortical cholecystokinin immunoreactive neurons have long projections. Exp Brain Res 1985; 59: 533-42.
22. Jevtic MR, Milovanovic. Physiological and physiotherapeutic basis of pain. Med Cas 2006; 1-2: 54-8. (in Serbian).

23. Jones EG, Stewart H. Co-localization of GABA and neuropeptides in cortical neurons. Trends Neurosci 1986; 9: 71-6.

24. O'Connor WT. Functional neuroanatomy of the ventral GABA pathway. New sites of intervention in the treatment of schizophrenia. J Neurosci Methods 2001; 109: 31-9.

25. Wei J, Hemmings GP. The CCK-A receptor gene possibly associated with auditory hallucinations in schizophrenia. Eur Psychiatry 1999; 14: 67-70.

26. Mauri MC, Rudelli R, Vanni S, et al. Cholecystokinin, beta-endorphin and vasoactive intestinal peptide in peripheral blood mononuclear cells of drug-naïve schizophrenic patients treated with haloperidol compared to healthy controls. Psychiatry Res 1998; 78: 45-50.

27. Ochi J, Ito M, Okuno T, Mikawa H. Immunoreactive leucine-enkephalin content in brains of epileptic mice. Epilepsia 1988; 29: 91-6.

28. Palkovits M, Fischer J. Karyometric investigations. Budapest: Akademiai Kiado, 1968.

29. Fröscher W, Majer V, Fritschi T. Periodic hypersomnia: Case report with biochemical and EEG findings. Sleep 1991;14: 460-3. 